\title{
KAJIAN KARAKTERISTIK SENSORIS FISIK DAN KIMIA KERUPUK \\ FORTIFIKASI DAGING LIDAH BUAYA (Aloe vera) DENGAN METODE PEMANGGANGAN MENGGUNAKAN MICROWAVE
}

\section{STUDY OF SENSORY CHARACTERISTICS, PHYSICAL, AND CHEMICAL PROPERTIES OF FORTIFIED CRACKERS WITH Aloe vera USING MICROWAVE ROASTING METHODS}

\author{
Nurwachidah Rosiani ${ }^{1}$ Basito $^{1}$, Esti Widowati. ${ }^{1}$ \\ ${ }^{I}$ Program Studi Ilmu dan Teknologi Pangan \\ Email: nurwachidahrosiani@ymail.com
}

\begin{abstract}
The purpose of the study of the sensory, physical, and chemical characteristics of crackers fortified meat aloe (Aloe vera) by using microwave roasting method is to determine the formulation of crackers with the addition of aloe vera preferred meat and know the characteristics of sensory, physical, and chemical crackers with the addition of aloe vera meat. This study uses the pattern completely randomized design (CRD) with a concentration factor of the aloe vera meat. Concentration of aloe vera meat used 0\%-39.9\%. Be repeated sample three times and two times repetition analysis. Data obtained on sensory testing, physical, and chemical analyzed using one-way ANOVA at $\alpha=0.05$ level. If there is a real difference, then followed by Duncan's Multiple Range Test Test (DMRT) at $\alpha=0.05$. The results showed that the addition of aloe vera meat significantly affect the sensory characteristics which include attributes of color, smell, flavor, texture, and overall. Formulations with the addition of meat crackers aloe vera is the most preferred meat at a concentration of $13.3 \%$ aloe vera. The addition of aloe vera meat significantly affect the physical characteristics which includes flower power, texture, and hygroscopicity and chemical characteristics which include moisture content, ash content, total protein, fat, and carbohydrates. From the results of chemical analysis, the concentration of the addition of aloe vera meat $13.3 \%$ have physical characteristics such as flower power by 186.73\%; hygroscopicity amounted to $0.2653 \mathrm{~g}$ and texture of $32.7349 \mathrm{~N}$ and chemical characteristics of the water content in the form of $\% 3.78 \%$; ash content of $5.75 \%$; total protein of 3.35\%; $0.29 \%$ fat and carbohydrate by $86.82 \%$.
\end{abstract}

Keywords: Crackers, Meat of Aloe Vera, and a Microwave

\begin{abstract}
ABSTRAK
Tujuan dari kajian karakteristik sensoris fisik dan kimia kerupuk fortifikasi daging lidah buaya (Aloe vera) dengan metode pemanggangan menggunakan microwave adalah untuk mengetahui formulasi kerupuk dengan penambahan daging lidah buaya yang disukai dan mengetahui karakteristik sensoris, fisik dan kimia kerupuk dengan penambahan daging lidah buaya. Penelitian ini menggunakan pola Rancangan Acak Lengkap (RAL) dengan satu faktor yaitu konsentrasi daging lidah buaya. Konsentrasi daging lidah buaya yang digunakan 0\%-39,9\%. Dilakukan pengulangan sampel sebanyak tiga kali dan dua kali pengulangan analisa. Data yang diperoleh pada pengujian sensori, fisik dan kimia dianalisis menggunakan one way ANOVA pada tingkat $\alpha=$ 0,05. Jika terdapat perbedaan nyata, maka dilanjutkan dengan uji Duncan Multiple Range Test (DMRT) pada $\alpha=$ 0,05. Penambahan daging lidah buaya berpengaruh nyata terhadap karateristik sensori yang meliputi atribut warna, aroma, rasa, tekstur dan keseluruhan. Formulasi kerupuk dengan penambahan daging lidah buaya yang paling disukai adalah pada konsentrasi daging lidah buaya sebesar 13,3\%. Penambahan daging lidah buaya berpengaruh nyata terhadap karakteristik fisik yang meliputi daya kembang, tekstur dan higrokopositas serta karakteristik kimia yang meliputi kadar air, kadar abu, protein total, lemak, dan karbohidrat. Dari hasil analisis kimia, konsentrasi penambahan daging lidah buaya 13,3\% memiliki karakteristik fisik berupa \% daya kembang sebesar 186,73; higrokopositas sebesar 0,2653 gr dan tekstur sebesar 32,7349 N serta karakteristik kimia berupa \% kadar air sebesar 3,78\%; kadar abu sebesar 5,75\%; protein total sebesar 3,35\%; lemak 0,29\% dan karbohidrat sebesar $86,82 \%$.
\end{abstract}

Kata Kunci : Kerupuk, Daging Lidah Buaya, dan Microwave 


\section{PENDAHULUAN}

Menurut Siaw et al., (1985), kerupuk merupakan salah satu makanan kecil yang bila digoreng mengalami pengembangan volume dan membentuk porus serta memiliki densitas yang rendah selama proses penggorengan.Konsumsi kerupuk biasanya bukan sebagai makanan utama melainkan sebagai makanan ringan atau sebagai pelengkap hidangan yang dikonsumsi dalam jumlah yang kecil dan digemari para penikmatnya.Kerupuk yang beredar di pasaran terbuat dari pati dan diberi bumbubumbu dan digoreng (Wiriono, 1984). Jenisjenis kerupuk yang beredar di pasaran antara lain kerupuk beras, kerupuk tapioka, kerupuk kedelai, kerupuk udang, dan lain sebagainya. Menurut Koswara (2009), sumber gizi yang terbesar dari kerupuk berasal dari pati yang banyak mengandung karbohidrat. Agar kerupuk memiliki nilai gizi yang lebih, maka perlu dilakukan inovasi dengan penambahan daging lidah buaya guna meningkatkan kandungan nutrisi mineral pada kerupuk.

Berdasarkan data dari Badan Pusat Statistik pertumbuhan lidah buaya di Indonesia pada tahun 2010 sebesar 4309 ton. Dalam industri, lidah buaya dimanfaatkan sebagai bahan baku obat, bahan kosmetik, dan bahan baku produk olahan makanan. Berdasarkan data dari Aloevera Center (2004) diketahui bahwa lidah buaya mengadung kadar air 95,5\%, lemak 0,067\%, karbohidrat $0,043 \%$, protein $0,038 \%$, vitamin A 4,59 IU dan vitamin C 3,47 Mg. Selain itu menurut Henry (1979), unsur utama dari cairan lidah buaya adalah aloin, emodin, resin, gum, dan unsur lainnya seperti minyak atsiri. Dari segi kandungan nutrisi, gel atau lendir daging lidah buaya mengandung beberapa mineral seperti $\mathrm{Zn}, \mathrm{K}, \mathrm{Fe}$, dan vitamin. Adanya penambahan daging lidah buaya dalam proses pembuatan kerupuk diharapkan dapat membentuk adonan yang tipis pada saat proses pencetakan, karena kandungan gum yang terdapat pada lidah buaya dapat digunakan untuk pengikatan flavor, bahan pengental, pemantap emulsi, dan pembentuk lapisan tipis. Gum akan membentuk larutan yang tidak begitu kental dan tidak membentuk gel pada kepekatan yang biasa digunakan (paling tinggi 50\%) (Alinkolis, 1989).

Menurut Muliawan (1991), proses pembuatan kerupuk meliputi pencampuran bahan baku, pembuatan adonan, pencetakan, pengukusan, pendinginan, pengirisan, pengeringan, dan pemasakan. Pada umumnya proses pembuatan kerupuk masih secara konvensional, begitu pula dengan pengolahannya. Berdasarkan karakteristik mutu, secara umum kerupuk memiliki tekstur yang renyah dan memiliki volume yang mengembang.

Umumnya untuk mendapatkan kerupuk matang, dilakukan sistem pemasakan menggunakan media minyak goreng yang disebut penggorengan. Menurut Siswantoro (2008), ditinjau dari segi waktu proses pemasakan, penggorengan adalah salah satu cara pemasakan produk pangan yang dilakukan secara cepat, dan cara ini dianggap paling efisien proses transfer panasnya ke produk pangan yang dimasak. Pada saat proses penggorengan minyak terserap ke dalam bahan, sehingga dapat mengurangi tingkat penerimaan konsumen dan mutu kerupuk menurun karena lebih cepat mengalami ketengikan. Dilihat dari segi kesehatan, konsumsi makanan yang mengandung minyak yang banyak akan cenderung mengakibatkan kolesterol dan jantung koroner. Secara aspek sosial, sekarang ini masyarakat lebih memilih makanan yang mengandung rendah lemak dengan tujuan untuk diet guna menghindari kelebihan berat badan serta menjaga kesehatan.

Pemasakan juga dapat dilakukan tanpa menggunakan media minyak goreng atau disebut dengan teknik pemasakan secara kering.Pemasakan kerupuk tanpa media minyak goreng dapat dilakukan menggunakan media pasir atau disebut penyangraian.Namun pada penyangraian kerupuk sering meninggalkan cemaran fisik, yaitu masih menempelnya sisa pasir pada permukaan kerupuk, sehingga perlu dilakukan alternatif pemasakan. Dalam penelitian ini dilakukan alternatif pemasakan menggunakan microwave sebagai media pemasakan tanpa minyak goreng. 
Microwaveoven merupakan salah satu alat pengolahan pangan.Kingston (1997), menjelaskan prinsip kerja dari microwave, yaitu radiasi gelombang mikro dilewatkan pada molekul air, lemak, maupun gula yang sering terdapat pada bahan makanan. Molekul-molekul ini akan menyerap energi elektromagnetik tersebut. Gelombang mikro merupakan hasil radiasi yang dapat ditransmisikan, dipantulkan atau diserap tergantung dari bahan yang berinteraksi dengannya.Microwave memanfaatkan 3 sifat dari gelombang mikro tersebut dalam proses memasak. Gelombang mikro dihasilkan oleh magnetron, gelombang tersebut ditransmisikan ke dalam waveguide, lalu gelombang tersebut dipantulkan ke dalam fan stirrer dan dinding dari ruangan didalam oven, dan kemudian gelombang tersebut diserap oleh makanan. Beberapa keuntungan kerupuk bila digoreng tanpa menggunakan media minyak terhadap mutu produk yaitu produk tidak mengandung minyak sehingga tidak mudah tengik dan apabila mengalami penurunan mutu (melempem) dapat dilakukan rekondisi, yaitu dengan cara dijemur atau dilakukan pemanasan pada suhu $35-45^{\circ} \mathrm{C}$ (Siswantoro, 2008).

Menurut Sya'bani (1998), pemasakan kerupuk menggunakan microwave oven dapat menggantikan penggorengan konvensional dengan minyak goreng serta dapat mengendalikan jumlah minyak dalam kerupuk goreng. Pada pemasakan menggunakan microwave oven, dimulai pada saat gelombang mikro yang mengenai kerupuk berinteraksi dengan air yang terkandung di dalam kerupuk dan mengakibatkan timbulnya panas.Pengembangan volume dimulai dengan pengembangan kerupuk di bagian tengah yang diikuti bagian pinggir kerupuk.Kerupuk hasil pemasakan menggunakan microwave oven, memiliki sifat organoleptik yang berbeda dengan kerupuk goreng konvensional.Kerupuk hasil pemasakan menggunakan microwave oven berwarna putih kusam dengan permukaan mulus dan tidak berminyak, struktur bagian dalam berongga dengan ukuran yang relatif seragam.Sedangkan kerupuk goreng konvensional berwarna agak kekuningan, permukaan tidak mulus, dan tampak berminyak.

Dalam penelitian Rosiani (2011) tentang proses produksi pembuatan kerupuk denganfortifikasi daging lidah buaya (Aloe vera)kaya antioksidan, dijelaskan bahwa pembuatan kerupuk dengan proses pematangannya menggunakan cara penggorengan dapat dilakukan inovasi terhadap komponen penyusunnya, yaitu dilakukan fortifikasi pembuatan kerupuk menggunakan daging lidah buaya. Berdasarkan penelitian tersebut, perlu dilakukan adanya penelitian lebih lanjut mengenai pengkajian karakteristik sensoris dan fisikokimia kerupuk dengan penambahan daging lidah buaya (Aloe vera).

Disadari bahwa penambahan daging lidah buaya dan teknik pemasakan kerupuk menggunakan microwaveoven merupakan inovasi baru, sehingga perlu dikaji mengenai formulasi penambahan daging lidah buaya, sifat sensori, sifat fisik, dan kimia, sehingga dapat mengetahui nilai gizi serta tingkat penerimaan konsumen terhadap produk yang dihasilkan.

\section{METODE PENELITIAN}

\section{Bahan dan Alat}

Bahan yang digunakan dalam pembuatan kerupuk fortifikasi daging lidah buayaantara lain lidah buaya "Aloe barbandis Miller dengan panjang pelepah $30 \mathrm{~cm}$ dan lebar $10 \mathrm{~cm}$ " dari supermarket Superindo Surakarta, tepung tapioka (Rose Brand), tepung terigu (Cakra Kembar), bakingpowder; garam dapur (Refina), gula (Gulaku) $\left(\mathrm{C}_{12} \mathrm{H}_{22} \mathrm{O}_{11}\right)$, dan bawang cutting, diperoleh dari Pasar Gede, Surakarta. Selain bahan untuk pengolahan kerupuk, juga digunakan bahan kimia pro analysis yang umumnya digunakan di laboratorium guna analisis kimia.Bahan-bahan kimia yang digunakan untuk analisis protein meliputi asam sulfat pekat $\left(\mathrm{H}_{2} \mathrm{SO}_{4}\right)$ (Merck), air raksa oksida ( $\mathrm{HgO})$, kalium sulfat $\left(\mathrm{K}_{2} \mathrm{SO}_{4}\right)$ (Merck), larutan natrium hidroksida-natrium tiosulfat $\left(\mathrm{NaOH}-\mathrm{NaS}_{2} \mathrm{O}_{2} .5 \mathrm{H}_{2} \mathrm{O}\right)$ (Merck), larutan asam borat jenuh $\left(\mathrm{H}_{2} \mathrm{BO}_{3}\right)$ (Merck), larutan asam klorida $(\mathrm{HCl})$ (Merck), aquadest $\left(\mathrm{H}_{2} \mathrm{O}\right)$, pereaksi metil merah 
$\left(\mathrm{C}_{14} \mathrm{H}_{14} \mathrm{~N}_{3} \mathrm{NaO}_{3} \mathrm{~S}\right)$, alkohol $\left(\mathrm{C}_{2} \mathrm{H}_{5} \mathrm{OH}\right)$, dan methylen blue $\left(\mathrm{C}_{16} \mathrm{H}_{18} \mathrm{~N}_{3} \mathrm{SCl}\right)$, serta bahan untuk analisis kadar lemak adalah benzena $\left(\mathrm{C}_{6} \mathrm{H}_{6}\right)$ (Merck).

Alat yang digunakan dalam pembuatan kerupuk fortifikasi daging lidah buaya meliputi : pisau, blender (Philips), panci pengukus, mangkok, sendok, kompor (Quantum), microwave oven (SHARP R200J), loyang pencetak $12 \times 12 \times 2 \mathrm{~cm}$, kompor listrik (Maspion), nampan kawat, dan cabinet driyer.

\section{Tahapan Penelitian}

\section{Kerupuk}

Tahap awal pada penelitian ini adalah pembuatan kerupuk fortifikasi daging lidah buaya mengadopsi dari penelitian Rosiani (2011). Untuk metode pemanggangan kerupuk mengadopsi dari penelitian Sya'bani (1996). Berikut ini tahapan proses dalam pembuatan kerupuk fortifikasi daging lidah buaya yang digoreng menggunakan microwave oven.

\section{Persiapan Bahan}

Pada awal proses bahan yang disiapkan meliputi lidah buaya dikupas sehingga mendapatkan daging lidah buaya, daging lidah buaya yang sudah dikupas dicuci hingga bersih, setelah dicuci bersih kemudian dilakukan proses blanching dengan suhu $100^{\circ} \mathrm{C}$ selama 3 menit, kemudian dihaluskan menggunakan blender. Setelah didapat bubur lidah buaya kemudian dicampur dengan tepung tapioka, tepung terigu, gula, garam, bawang putih, dan baking powder.

\section{Pembuatan Adonan}

Tahap pembuatan adonan merupakan tahap awal yang sangat penting. Dalam proses pembuatan adonan bahan-bahan yang telah disiapkan dimasukkan ke dalam suatu wadah kemudian diaduk hingga homogen.

\section{Pencetakan}

Setelah terbentuk adonan kemudian dilakukan pencetakan. Alat yang digunakan dalam pencetakan kerupuk ini adalah loyang berbentuk persegi dengan ukuran $12 \times 12 \times 1 \mathrm{~cm}$. Pencetakan ini bertujuan untuk menyeragamkan bentuk dari kerupuk.

\section{Pengukusan}

Pengukusan dilakukan pada suhu $100^{\circ} \mathrm{C}$ selama 15 menit. Dalam proses pengukusan ini terjadi gelatinisasi pati yang berkaitan erat dengan proses pengembangan kerupuk saat digoreng.

\section{Pendinginan}

Pendinginan ini bertujuan supaya tekstur lebih keras dan tidak lembek dan proses pengeringan lebih cepat.

\section{Pemotongan}

Pemotongan ini bertujuan untuk menyeragamkan ukuran. Dalam proses pemotongan ini adonan kerupuk yang telah dikukus dan didinginkan kemudian dipotong dengan ukuran $1,5 \times 2,5 \mathrm{~cm}$.

\section{Pengeringan}

Pengeringan ini bertujuan untuk mengurangi kadar air pada kerupuk supaya dalam proses pemanggangan kerupuk dapat mengembang sempurna. Pengeringan ini dilakukan menggunakan cabinet driyer selama 5-6 jam dengan suhu $60^{\circ} \mathrm{C}$ sampai kadar air sekitar $12 \%$.

\section{Pemanggangan}

Pemanggangan merupakan tahap akhir dalam proses pembuatan kerupuk. Pada umumnya kerupuk digoreng menggunakan minyak, namun dalam penelitian ini, untuk mendapatkan kerupuk kerupuk matang dilakukan pemanggangan menggunakan microwave dengan suhu high $\left(125^{\circ} \mathrm{C}\right)$ selama 2 menit.

\section{Analisis Sensori, Fisik dan Kimia}

Setelah produk selesai dibuat, kemudian dilakukan penelitian pendahuluan yaitu penelitian sensori pada sampel. Uji sensori yang digunakan adalah uji kesukaan skoring. Pemilihan uji skoring guna mengetahui tingkat kesukaan atau penerimaan panelis terhadap karakteristik sensori kerupuk. Karakteristik sensori yang diuji meliputi tekstur, rasa, warna, aroma, dan keseluruhan. Hasil dari uji sensori ditujukan untuk mengetahui satu atau beberapa sampel yang disukai oleh panelis. Pada penilaian uji sensori menggunakan metode uji skoring menggunakan skala numerik. Ada lima skala penilaian dalam uji skoring ini yaitu (1) suka, (2) agak suka, (3) netral, (4) agak tidak suka, dan (5) tidak suka. 
Setelah dilakukan pengujian sensori, dilanjutkan pengujian fisik dan kimia kerupuk. Sampel diulang sebanyak 3 kali dan dianalisa dengan dua kali pengulangan analisis. Sampel diuji karakteristik fisiknya baik tekstur, daya pengembangan, dan higroskopositas, sedangkan karakteristik kimianya yaitu air, abu, protein, lemak, dan karbohidrat. Analisis fisik ditujukan untuk mengetahui tingkat kekerasan kerupuk, tingkat pengembangan kerupuk lidah buaya ketika dipanggang menggunakan microwave, dan kemampuan kerupuk dalam penyerapan air. Analisis kimia ditujukan untuk mengetahui banyaknya kandungan air, abu, protein, lemak, dan karbohidrat pada masingmasing kerupuk fortifikasi daging lidah buaya.

\section{Rancangan Percobaan dan Analisis Data}

Rancangan Percobaan yang digunakan pada penelitian ini adalah Rancangan Acak Lengkap (RAL) dengan satu faktor yaitu jumlah penambahan daging lidah buaya. Analisis data sensori menggunakan software SPSS versi 17. Data yang diperoleh dari sensori dianalisis menggunakan One Way ANOVA pada tingkat kepercayaan $95 \%$ atau $\alpha=0,05$ untuk mengetahui ada atau tidaknya perbedaan atau pengaruh pada tiap formula. Jika terdapat perbedaan nyata, maka dilanjutkan dengan uji Duncan Multiple Range Test (DMRT) pada tingkat $\alpha=0,05$. Penilaian formula terbaik berdasarkan penilaian pada tiap aspek sensori dan penilaian terbaik secara keseluruhan.

\section{HASIL DAN PEMBAHASAN}

\section{Karakteristik Sensori Kerupuk}

Evaluasi sensori dapat digunakan untuk menilai adanya perubahan yang dikehendaki atau tidak dikehendaki dalam suatu produk. Dalam penelitian ini dilakukan analisis sensori guna mengetahui tingkat penerimaan sensori panelis terhadap kerupuk dengan penambahan daging lidah buaya. Uji sensori yang digunakan dalam penelitian ini adalah uji skoring dengan jumlah 35 panelis. Atribut yang diujikan pada analisis sensori ini meliputi warna, aroma, rasa, tekstur dan keseluruhan. Hasil uji sensori dapat dilihat pada Tabel 2.

Berdasarkan hasil uji sensori pada Tabel 2., dapat diketahui bahwa pada tabel tesebut terdapat angka yang berbeda-beda, serta diikuti adanya tambahan huruf pada masing-masing nilai. Dapat kita ketahui bahwa semakin tinggi nilai sensori, maka semakin rendah tingkat penerimaan panelis terhadap produk yang diuji. Huruf yang mengikuti nilai menunjukkan bahwa apabila huruf yang sama menunjukkan tidak terdapat beda nyata namun jika huruf berbeda menunjukkan terdapat perbedaan nyata pada kolom. Dilihat dari masing-masing atribut pada Tabel 2. dapat diketahui ada tidaknya pengaruh penambahan daging lidah buaya terhadap kerupuk. Berikut penjelasan masing-masing atribut sensori yang meliputi warna, aroma, rasa, tekstur dan keseluruhan.

\subsection{Warna}

Faktor warna sangat menentukan penilaian bahan pangan sebelum faktor-faktor lain dipertimbangkan secara visual.

Penerimaan warna suatu bahan berbeda-beda tergantung dari faktor alam, geografis, dan aspek sosial masyarakat penerima. Warna juga dapat digunakan sebagai indikator kesegaran atau kematangan (Winarno, 1992). Hasil uji sensori untuk atribut warna dapat dilihat pada Tabel 2 ..

Berdasarkan Tabel 2.dapat diketahui bahwa terdapat perbedaan nyata pada kerupuk fortifikasi daging lidah buayadengan konsentrasi $26,6 \%$ dan 39,9\%. Namun pada konsetrasi $13,3 \%$ tidak berpengaruh nyata terhadap tingkat penerimaan kontrol. Maka dapat kita ketahui bahwa semakin tinggi penambahan daging lidah buaya maka semakin berkurang tingkat kesukaan panelis terhadap warna kerupuk. Hal ini disebabkan karena semakin tinggi penambahan daging lidah buaya tingkat kecerahan warna setelah digoreng semakin turun.

Menurut Winarno (1997), warna dalam bahan dapat berasal dari pigmen alami bahan pangan itu sendiri, reaksi karamelisasi, reaksi Maillard, reaksi senyawa organik dengan udara, dan penambahan zat warna baik alami maupun sintetik. 
Tabel 1. Formulasi Penambahan Daging Lidah Buaya

\begin{tabular}{lcccc}
\hline \multirow{2}{*}{ Bahan } & \multicolumn{4}{c}{ Formulasi (\%) } \\
\cline { 2 - 5 } & $\mathrm{A} 1$ & $\mathrm{~A} 2$ & $\mathrm{~A} 3$ & $\mathrm{~A} 4$ \\
\hline Tapioka & 86,8 & 74,7 & 62,6 & 50,5 \\
Terigu & 8,68 & 7,47 & 6,26 & 5,05 \\
Daging lidah buaya & 0 & 13,3 & 26,6 & 39,9 \\
Bawang putih & 1,5 & 1,5 & 1,5 & 1,5 \\
Gula & 1 & 1 & 1 & 1 \\
Garam & 1,5 & 1,5 & 1,5 & 1,5 \\
Baking powder & 0,5 & 0,5 & 0,5 & 0,5 \\
\hline
\end{tabular}

Tabel 2. Karakteristik Sensori Kerupuk Dengan Penambahan Daging LidahBuaya

\begin{tabular}{cccccc}
\hline Kosentrasi (\%) & Warna & Aroma & Rasa & Tekstur & Keseluruhan \\
\hline $0 \%$ & $1,14^{\mathrm{a}}$ & $1,62^{\mathrm{a}}$ & $1,77^{\mathrm{a}}$ & $1,17^{\mathrm{a}}$ & $1,42^{\mathrm{a}}$ \\
$13,3 \%$ & $1,48^{\mathrm{a}}$ & $1,48^{\mathrm{a}}$ & $1,02^{\mathrm{a}}$ & $1,51^{\mathrm{a}}$ & $1,51^{\mathrm{a}}$ \\
$26,6 \%$ & $2,91^{\mathrm{b}}$ & $2,80^{\mathrm{b}}$ & $2,68^{\mathrm{c}}$ & $2,74^{\mathrm{b}}$ & $2,91^{\mathrm{b}}$ \\
$39,9 \%$ & $4,08^{\mathrm{c}}$ & $4,08^{\mathrm{c}}$ & $4,08^{\mathrm{d}}$ & $4,00^{\mathrm{c}}$ & $4,08^{\mathrm{c}}$ \\
\hline
\end{tabular}

Keterangan : Angka yang diikuti huruf superscript yamg berbeda pada tiap kolom menunjukkan adanya beda nyata pada tingkat $\alpha=0,05$. Skala nilai 1) sangat suka, 2) suka, 3) netral, 4) agak tidak suka, 5) tidak suka.

Warna kerupuk semakin coklat dengan bertambahnya persentase penambahan daging lidah buaya, hal ini dipengaruhi oleh adanya reaksi Maillard. Perubahan warna kerupuk yang diakibatkan adanya reaksi pencoklatan non enzimatis dapat terjadi dikarenakan kandungan gizi kerupuk yang banyak mengandung karbohidrat dan sedikit protein, sehingga gula pereduksi akan bereaksi dengan gugus amina primer dari protein yang menghasilkan pigmen melanoidin yang dapat mengakibatkan warna coklat pada kerupuk (Ketaren, 1986). Menurut Martins (2001), reaksi Maillard terkait dengan aroma, rasa dan warna terutama dalam makanan seperti proses pemanggangan biji kopi, roti, sereal dan pemasakan daging. Terjadinya reaksi Maillard dalam penelitian ini yaitu ketika kerupuk mengalami proses pengukusan dan pemangangan.

\subsection{Aroma}

Uji sensori dengan atribut aroma ditunjukkan untuk mengetahui tingkat kesukaan panelis terhadap aroma kerupuk dengan penambahan lidah buaya. Hasil uji sensori untuk atribut aroma dapat dilihat pada Tabel 2.. Pada atribut aroma ini dapat diketahui adanya perbedaan nyata terhadap penerimaan panelis terhadap kerupuk dengan kosentarsi penambahan lidah buaya 26,6\% dan 39,9\%. Namun pada konsentrasi penambahan $13,3 \%$ tidak mengalami perbedaan nyata dengan kontrol.

Semakin tinggi konsentrasi peanambahan daging lidah buaya mengakibatkan penurunan tingkat penerimaan panelis terhadap aroma kerupuk. Hal ini disebabkan aroma langu yang terdapat pada kerupuk. Aroma langu tersebut dikarenakan lidah buaya memiliki senyawa volatil berupa minyak atsiri (Jatinka, 2009).

\subsection{Rasa}

Menurut deMan (1997), pada umumnya rasa yang telah disepakati ada empat rasa yaitu manis, pahit, asam, dan asin. Kepekaan tehadap rasa terdapat pada kuncup rasa pada lidah. Hubungan antara struktur kimia suatu senyawa lebih mudah ditentukan dengan rasanya. Hasil uji sensori untuk atribut rasa dapat dilihat pada Tabel 2.. Dari hasil uji sensori yang telah dilakuakan dapat diketahu bahwa penambahan daging lidah buaya dengan konsentrasai $26,6 \%$ dan $39,9 \%$ memiliki hasil yang berbeda nyata dengan kontrol namun pada penambahan daging lidah buaya dengan konsentrasi 13,3\% memiliki hasil yang tidak berbeda nyata dengan kontrol. 
Tabel 3. Karakteristik Fisik Kerupuk Dengan Penambahan Daging Lidah Buaya

\begin{tabular}{cccc}
\hline Kosentrasi (\%) & Daya Kembang(\%) & Higrokopositas (gr) & Tekstur(N) \\
\hline $0 \%$ & $198,47^{\mathrm{a}}$ & $0,2477^{\mathrm{a}}$ & $34,5257^{\mathrm{a}}$ \\
$13,3 \%$ & $186,73^{\mathrm{b}}$ & $0,2653^{\mathrm{b}}$ & $32,7349^{\mathrm{a}}$ \\
$26,6 \%$ & $167,29^{\mathrm{c}}$ & $0,2933^{\mathrm{c}}$ & $29,9636^{\mathrm{ab}}$ \\
$39,9 \%$ & $153,72^{\mathrm{d}}$ & $0,3337^{\mathrm{d}}$ & $22,4369^{\mathrm{b}}$ \\
\hline
\end{tabular}

Keterangan: Angka yang diikuti huruf superscript yamg berbeda pada tiap kolom menunjukkan adanva beda nvata pada tingkat $\alpha=0,05$

Dari hasil analisis sensori pada Tabel 2. bahwa tingkat penerimaan tertinggi panelis pada kerupuk fortifikasi daging lidah buayapada konsentrasi 13,3\%. Konsentrasi penambahan lidah buaya terlalu banyak mengakibatkan tingkat penerimaan panelis yang rendah dimungkinkan karena rasa pahit yang ditimbulkan terlalu kuat. Rasa pahit yang terdapat pada kerupuk lidah buaya disebabkan karena pada daging lidah buaya memiliki senyawa flavonoid dan terpenoid (Nurdiani, 2012). Selain itu, reaksi Maillard juga dapat mempengaruhi rasa pada kerupuk. Hasil reaksi pencoklatan non-enzimatis menghasilkan bahan berwarna colkat yang sering dikehendaki terutama untuk memperoleh flavor, warna dan rasa yang khas pada makanan yang mengalami proses pemanggangan, terkadang menjadi suatu pertanda penurunan mutu karena terjadi perubahan flavor, warna dan nilai gizi dari bahan pangan tersebut (Winarno, 1994).

Rasa yang ditimbulkan pada kerupuk dipengaruhi oleh komposisi bumbu yang dicampurkan pada saat pengolahan kerupuk. Rasa yang dihasilkan pada kerupuk fortifikasi daging lidah buaya ini adalah agak asin. Menurut Hudayan dan Darajat (1980), dalam industri pangan, fungsi utama dari garam adalah sebagai pemberi rasa. Garam biasanya dapat dikenali dengan baik dengan natrium klorida. Natrium klorida memperkuat rasa pada mulut, kemanisan, keseimbangan, dan juga menutupi atau mengurangi ciri yang menyimpang.

\subsection{Tekstur}

Tekstur merupakan antribut yang penting dalam makanan renyah seperti kerupuk. Setiap makanan memiliki tekstur serta tingkat kesukaan panelis yang beragam. Sehingga dilakukan uji sensori guna mengetahui tingkat kesukaan panelis terhadap tekstur dari kerupuk dengan penambahan daging lidah buaya. Tekstur yang diuji disini adalah penerimaan panelis terhadap teksur kerupuk saat digigit ataupun dikunyah. Hasil uji sensori kerupuk dengan penambahan lidah buaya untuk atribut tekstur dapat dilihat pada Tabel 2.

Dari hasil analisis sensori pada parameter tekstur dapat kita ketahui bahwa semakin tinggi penambahan daging lidah buaya pada kerupuk, maka semakin turun tingkat kesukaan konsumen.

Pada kerupuk fortifikasi daging lidah buayadengan konsentrasi $13,3 \%$ berbeda nyata dengan kerupuk pada konsentrasi $26,6 \%$ dan 39,9\%. Kerupuk dengan konsentrasi 13,3\% masih disukai oleh panelis dikarenakan kerupuk yang dihasilkan memiliki tekstur yang renyah dibanding kerupuk fortifikasi daging lidah buayapada konsentrasi $26,6 \%$ dan $39,9 \%$ sehingga kerupuk cenderung keras. Hal ini dikarenakan semakin tinggi penambahan daging lidah buaya, maka semakin rendah jumlah penambahan tepung tapioka dan terigu, sehingga kandungan pati pada kerupuk semakin rendah.

Pada dasarnya komponen utama yang mendominasi dalam pembuatan kerupuk adalah pati. Pati mempunyai dua komponen utama yaitu amilosa (fraksi larut) dan amilopektin (fraksi tidak larut). Amilopektin merupakan salah satu komponen pati yang mempengaruhi daya kembang kerupuk. Menurut Zulfani (1992), amilopektin berfungsi sebagai pemberi sifat renyah pada kerupuk. Kerupuk dengan kandungan amilopektin tinggi memiliki daya kembang yang tinggi dan sifat keerenyahan yang tinggi pula. Hali ini dikarenakan dalam proses pemanasan akan terjadi prosses gelatinisasi pati dan akan terbentuk struktur yang elastis yang dimungkinkan untuk dapat mengembangkan volume krupuk pada proses pemanggangan atau pemangangan sehingga 
memiliki kerenyahan yang tinggi pula. Selain pengaruh jumlah pati, faktor lain yang mempengaruhi tekstur dari kerupuk adalah jumlah air yang teruapkan pada saat pemanggangan atau pemasakan. Semakin banyak kadar air yang tidak teruapkan, maka semakin mengurangi keporosan kerupuk sehingga kerenyahan menurun. Menurut Susanto (1995), semakin banyak air yang teruapkan selama proses pemanggangan atau pemanggangan, maka volume pengembangan kerupuk akan semakin kecil dan tingkat kerenyahan kerupuk juga menurun.

\subsection{Keseluruhan}

Secara keseluruhan tingkat kesukaan panelis terhadap kerupuk fortifikasi daging lidah buayadengan kosentrasi 39,9\% berbeda nyata pada tingkat kepecayaan $95 \%$ dengan kerupuk dengan konsentrasi $26,6 \%$ dan $13,3 \%$. Semakin tinggi penambahan daging lidah buaya, maka semakin menurun tingkat kesukaan panelis terhadap kerupuk. Hal ini sesuai dengan keempat atribut lainnya yaitu warna, aroma, rasa, dan tekstur, karena keempat parameter tersebut mengalami penurunan tingkat kesukaan.

\section{Karateristik Fisik}

Karakteristik fisik merupakan hal yang penting dan perlu diamati dalam makanan. Salah satu karakteristik fisik pada makanan yang paling penting adalah tekstur. Tekstur merupakan segi penting untuk menentukan mutu dari makanan, bahan terkadang lebih penting dibanding dengan warna (deMan, 1997). Hal itu menunjukkan karakteristik fisik pada makanan tidak boleh dikesampingkan. Untuk karakteristik fisik yang diuji dalam penelitian ini meliputi daya kembang, tekstur, dan higrokopositas. Hasil analisis fisik kerupuk fortifikasi daging lidah buayadapat dilihat pada Tabel 3. Masingmasing karakteristik fisik makanan baik daya kembang, tekstur, dan higrokopositas memberikan peran yang berbeda-beda pada kerupuk dengan penambahan daging lidah buaya. Berikut ini penjelasan dari masingmasing karakteristik kerupuk dengan penambahan daging lidah buaya.

\subsection{Daya Kembang}

Salah satu penentu mutu kerupuk yang baik adalah daya kembang karena menentukan penerimaan konsumen. Menurut Susanti (2007), pengembangan dapat terjadi karena disebabkan oleh terbentuknya ronggarongga udara yang dipengaruhi oleh suhu, sehingga menyebabkan air yang terikat dalam gel menjadi uap. Daya kembang kerupuk sangat berkaitan dengan pati yang ada dalam produk. Pada dasarnya fenomena pengembangan kerupuk disebabkan oleh tekanan uap yang terbentuk dari pemanasan, sehingga kandungan air pada bahan mendesak struktur bahan yang menyebabkan produk mengembang (Qinah, 2009).

Dari Tabel 3. dapat kita ketahui volume pengembangan kerupuk berkisar antara 198,47-153,72\%. Semakin tinggi penambahan daging lidah buaya pada kerupuk mengakibatkan semakin rendah daya kembang kerupuk. Karena semakin tinggi penambahan daging lidah buaya mempengaruhi proses gelatinisasi pati dari tapioka sehingga proses perpindahan air ke granula pati yang membentuk gel akan terharmbat, sehingga mempengaruhi pengembangan kerupuk. Menurut Kusumaningrum (2009), faktor yang mempengaruhi faktor yang mempengarui daya kembang kerupuk dapat dilihat dari amilopektin, dan pengadukan.

Salah satu faktor yang mempengaruhi daya kembang kerupuk adalah amilopektin. Gelatinisasi merupakan proses pembengkakan granula pati, sehingga pada peristiwa ini granula tidak dapat kembali ke kondisi semula. Pada peristiwa gelatinisasi pati ini, molekul air akan masuk ke bagianbagian pati yang akan membentuk ikatanikatan gel pati. Untuk mendapatkan pengambangan volume kerupuk yang maksimum, kadar air yang terikat harus menyebar merata. Hal ini dapat dilakukan dengan menghomogenkan adonan sehingga proses gelatinisasi terjadi secara sempurna dan kandungan air tersebar secara merata (Koswara, 2009).

\subsection{Higrokopositas}

Higrokopositas merupakan kemampuan suatu produk dalam menyerap air. Nilai 
higrokopositas dapat dihitung bedasarkan selisih antara berat awal dan berat akhir ketika sampel sudah melempem. Kerupuk dengan atau tanpa penambahan lidah buaya dibiarkan selama 12 jam pada suhu $28-37^{\circ} \mathrm{C}$ dan kelembaban berkisar antara 54-64\%. Pengukuran berat produk, suhu, dan RH dilakukan secara aktual 3 jam sekali selama 12 jam. Untuk hasil uji hogrokopositas dapat dilihat pada Tabel 3.

Kerupuk merupakan bahan pangan yang memiliki kadar air yang rendah. Tingkat penyerapan air kerupuk tergantung tehadap kondisi lingkungan disekitar. Lingkungan yang memiliki RH tinggi mengakibatkan kerupuk cepat menyerap air dari lingkungan sebagai reaksi untuk menuju kondisi keseimbangan yang akan menyebabkan kerupuk menjadi melempem. Dapat kita ketahui bahwa nilai higrokopositas kerupuk fortifikasi daging lidah buayaberkisar antara 0,2477-0,3337 gr. Semakin tinggi penambahan daging lidah buaya, semakin tinggi pula nilai higrokopositas kerupuk. Hal ini disebabkan air pada bahan pangan yang melarutkan dan melunakkan matriks pati dan protein pada sebagian bahan pangan mengakibatkan perubahan kekuatan mekanik termasuk kerenyahan kerupuk (Katz dan Labuza, 1981).

Faktor lain yang mempengaruhi higrokopositas adalah volume pengembangan. Dalam penelitian Setyowati (2010) disebutkan bahwa daya kembang kerupuk berpengaruh terhadap higrokopositas. Volume pengembangan berbading lurus dengan higrokopositasnya. Volume pengembangan tinggi menyebabkan rongga udara semakin banyak sehingga jumlah air yang diserap semakin tinggi.

\subsection{Tekstur}

Menurut deMan (1997), tekstur merupakan bagian penting dari mutu makanan, kadang-kadang tekstur tersebut lebih penting dari pada warna, bau, dan rasa. Tekstur mempengaruhi citra makanan. Tekstur sangat penting pada makanan lunak dan makanan rangup atau renyah. Teksturakan mempengaruhi cita rasa yang ditimbulkan oleh bahan tersebut. Perubahan tekstur dan konsistensi bahan dapat mengubah rasa dan bau yang timbul karena dapat mempengaruhi kecepatan timbulnya rangsangan terhadap sel olfaktori dan kelenjar air liur (Winarno, 2002).

Pengukuran tekstur dalam penelitian ini dilakukan menggunakan alat Llyod Universal Machine.Instrumen ini digunakan untuk mengetahui profil tekstur pada makanan seperti kekerasan atau kerapuhan. Prinsip dari dariLlyod Universal Machine ini adalah menekan produk hingga retak atau patah pada produk, kemudian output diterjemahkan ke komputer dalam bentuk satuan Newton. Hasil pengujian tekstur dapat dilihat pada Tabel 3.. Pada masing-masing konsentrasi penambahan daging lidah buaya menunjukkan hasil berkisar antara 34,525722,4369 N. Semakin tinggi penambahan daging lidah buaya, menunjukkan semakin kecil gaya penekan. Semakin tinggi angka penekanan, maka semakin tinggi pula tingkat kekerasan. Menurut Winarno (1997), kerenyahan pada kerupuk timbul akibat terbentuknnya rongga-rongga udara pada proses pengembangan pada saat proses pemanggangan atau pemanggangan.

Faktor lain yang dapat mempengaruhi tekstur pada kerupuk adalah kadar air. Kadar air yang tinggi akan membentuk tekstur bahan pangan menjadi lebih lunak (Pradipta, 2011). Semakin berkurang kadar air, maka tekstur bahan pangan akan semakin keras. Selain itu, volume pengembangan juga dapat mempengaruhi tekstur.

Semakin tinggi penambahan daging lidah buaya kerupuk yang dihasilkan semakin dan maka kadungan air pada kerupuk semakin tinggi. Tipisnya kerupuk dipengaruhi oleh kandungan gum pada gel lidah buaya.

Mekanisme gum dalam pembuatan adonan kerupuk yaitu gel lidah buaya mempunyai mekanisme pembentukan sebagai berikut, apabila senyawa polimer / makromolekul (struktur kompleks) yang bersifat hidrofil / hidrokoloid didispersikan ke dalam air, maka akan mengembang. 
Tabel 4. Karakteristik Kimia Kerupuk Dengan Penambahan Daging Lidah Buaya

\begin{tabular}{clcccc}
\hline $\begin{array}{c}\text { Konsentrasi } \\
(\%)\end{array}$ & Kadar Air & Kadar Abu & Protein & Lemak & Karbohidrat \\
\hline $0 \%$ & $3,51^{\mathrm{a}}$ & $5,42^{\mathrm{a}}$ & $3,52^{\mathrm{c}}$ & $0,25^{\mathrm{a}}$ & $87,29^{\mathrm{b}}$ \\
$13,3 \%$ & $3,78^{\mathrm{ab}}$ & $5,75^{\mathrm{a}}$ & $3,35^{\mathrm{c}}$ & $0,29^{\mathrm{a}}$ & $86,82^{\mathrm{b}}$ \\
$26,6 \%$ & $3,99^{\mathrm{b}}$ & $6,47^{\mathrm{b}}$ & $3,14^{\mathrm{b}}$ & $0,36^{\mathrm{ab}}$ & $86,04^{\mathrm{a}}$ \\
$39,9 \%$ & $4,07^{\mathrm{b}}$ & $7,22^{\mathrm{c}}$ & $2,78^{\mathrm{a}}$ & $0,44^{\mathrm{b}}$ & $85,49^{\mathrm{a}}$ \\
\hline
\end{tabular}

Keterangan : Angka yang diikuti huruf superscript yamg berbeda pada tiap kolom menunjukkan adanya beda nyata pada tingkat $\alpha=0,05$.

Kemudian terjadi proses hidrasi molekul air melalui pembentukan ikatan hidrogen, dimana molekul-molekul air akan terjebak di dalam struktur molekul kompleks tersebut dan akan terbentuk masa gel yang kaku/kenyal.

\section{Karakteristik Kimia}

Menurut Legowo (2004), komponen bahan pangan merupakan senyawa kimia yang memiliki karakteristik tertentu. Komponen bahan pangan terdiri dari air, protein, karbohdrat, vitamin dan lemak, dan beberapa senyawa minor lain. Untuk karakteristik kimia yang diuji dari penelitian ini meliputi kadar air, abu, protein, lemak dan karbohidrat. Hasil analisis kimia kerupuk fortifikasi daging lidah buayadapat dilihat pada Tabel 4. Dari hasil analisis kimia, diperoleh hasil bahwa semakin tinggi penambahan daging lidah buaya, maka semakin tinggi kadar air, kadar abu, protein, dan lemak pada kerupuk, namun kandungan karbohidrat mengalami penurunan.

Kandungan kimia yang diinginkan pada kerupuk fortifikasi daging lidah buaya diharapkan masih dalam batas wajar pada SNI 01-2713-1999 mengenai kerupuk. Beberapa standar yang dipersyaratkan pada SNI 01-2713-1999 antara lain kadar air maksimal $11 \%$, kadar abu maksimal $0,2 \%$, protein minimal $6 \%$, dan lemak $0,5 \%$.

\subsection{Kadar Air}

Air merupakan karakteristik yang sangat penting pada bahan pangan, karena air dapat mempengaruhi kenampakan, tekstur, dan rasa bahan pangan. Kadar air dalam bahan pangan ikut menentukan kesegaran dan daya awet bahan pangan tersebut (Winarno, 2002). Pentingnya air dalam bahan pangan perlu adanya pemahaman yang
lebih.Adanya air juga mempengaruhi kemerosotan mutu makanan secara kimia dan mikrobiologi. Begitu pula penghilangan air (pengeringan) atau pembekuan air sangatlah penting pada beberapa metode pengawetan makanan (de Man, 1997).

Berdasarkan pentingnya peranan air dalam bahan pangan menunjukkan bahwa air sangatlah vital bagi makanan dari segi kenampakan, tekstur, cita rasa, maupun keawetannya. Sehingga dalam penelitian ini perlu dilakukan analisis kadar air guna mengetahui banyaknya air yang terkadung pada kerupuk dengan penambahan daging lidah buaya. Hasil analisis kadar air dapat dilihat pada Tabel 4.

Dari hasil analisis kimia kadar air dapat diketahui bahwa setiap penambahan daging lidah buaya 13,3\% mengakibatkan kenaikan kadar air kerupuk. Hal ini disebabkan karena lidah buaya memiliki kandungan air yang besar yaitu sebesar 95\% (Jatnika, 2009). Kenaikan kadar air pada kerupuk ini berpengaruh terhadap tekstur dan daya kembang kerupuk saat digoreng atau dipanggang. Kadar air yang tinggi pada kerupuk akan mengakibatkan kerupuk mudah melempem. Terlihat pada Tabel 4. bahwa semakin tinggi penambahan daging lidah buaya terlihat adanya penurunan daya penekanan pada kerupuk. Menurut Pradipta (2011), bahwa peningkatan kadar air pada bahan berbanding terbalik dengan gaya penekanan dan daya kembang (Muliawan, 1991).

\subsection{Kadar Abu}

Menurut Sudarmaji, dkk (1997), abu merupakan zat anorganik sisa hasil pembakaran suatu bahan organik. Kadar abu ada hubungannya dengan mineral suatu bahan. Penentuan kadar abu dilakukan 
dengan cara mengoksidasikan bahan pada suhu yang tinggi yaitu sekitar $500-600^{\circ} \mathrm{C}$ dan kemudian melakukan penimbangan zat yang tertinggal setelah proses pembakaran tersebut (Sudarmadji dkk., 1997). Sisa pembakaran yang berupa zat organik memiliki komponen yang meliputi kalsium, kalium, natrium, besi, mangan, magnesium, dan iodium. Unsurunsur mineral tersebut di dalam tubuh berfungsi sebagai zat pembangun dan pengatur (Winarno, 1997).

Berdasarkan Tabel 4. diketahui bahwa semakin tinggi penambahan daging lidah buaya semakin tinggi pula kadar abu dari kerupuk dan memiliki hasil yang berbeda nyata pada masing-masing konsentrasi penambahan daging lidah buaya. Hasil analisis kadar abu berkisar antara 5,42$7,22 \%$. Kadar abu berkaitan erat dengan kandungan mineral dalam bahan. Mineral dalam bahan pangan biasanya ditentukan dengan pembakaran, kemudian hasil pembakaran merusak senyawa organik dan meninggalkan mineral (deMan, 1997). Mineral yang terkadung dalam kerupuk dipengaruhi oleh adanya penambahan lidah buaya. Mineral yang terkandung dalam lidah buaya yaitu kalsium, fosfor, besi, magnesium, mangan, kalium, natrium dan tembaga (Furnawati, 2003).

\subsection{Protein}

Protein merupakan salah satu komponen kimia yang penting bagi tubuh dan memiliki peran yang sangat vital. Sumber protein terdapat pada produk hewan maupun produk tumbuhan (deMan, 1997). Menurut Sudarmadji dkk., (1997), protein merupakan salah satu kelompok bahan makronutrien. Protein memiliki struktur yang mengandung $\mathrm{N}$, disamping $\mathrm{C}, \mathrm{H}, \mathrm{O}$ (seperti juga karbohidrat dan lemak), $\mathrm{S}$ dan kadangkadang $\mathrm{P}, \mathrm{Fe}$, dan $\mathrm{Cu}$ (sebagai senyawa komplek sebagai protein). Seperti senyawa polimer lain (misalnya selulosa, pati) atau senyawa-senyawa hasil kondensasi beberapa unit molekul (misalnya trigliserida) maka protein juga dapat dihidrolisis atau diuraikan menjadi komponen unit-unitnya oleh molekul air. Hidrolisis pada protein akan melepas asam-asam amino penyusunnya.
Berdasarkan hasil analisis protein bahwa dari masing-masing kosentrasi penambahan daging lidah buaya $0 \%$ dan $13,3 \%$ menunjukkan hasil yang tidak berbeda nyata, namun berbeda nyata konsentrasi penambahan lidah buaya $26,6 \%$ dan $39,9 \%$. Semakin tinggi penambahan daging lidah buaya semakin rendah kadar protein pada kerupuk. Hasil analisis protein pada kerupuk fortifikasi daging lidah buaya berkisar antara $3,52-2,78 \%$. Hal ini dikarenakan lidah buaya memiliki kandungan protein yang relatif rendah yaitu 0,038\% (Furnawati, 2003).

\subsection{Lemak}

Pada pemasakan konvensional untuk mendapatkan kerupuk matang dilakukan penggorengan menggunakan media minyak, namun dalam proses ini minyak akan terserap dalam bahan yang dapat menimbulkan ketengikan dan meningkatkan kandungan lemak pada kerupuk. Seiring berjalanya waktu dengan adanya kemajuan teknologi pemanggangan dapat dilakukan menggunakan media pasir, oven dan oven dengan glombang micro atau yang lebih dikenal dengan microwave sehingga produk memiliki kadungan lemak yang rendah (Siswantoro, 2008). Mekanisme pemanggangan kerupuk menggunakan moicrowave. Menurut Carrol (1998), gelombang mikro berubah menjadi panas jika berinteraksi dengan bahan makanan. Hal ini disebabkan adanya gaya tarik menarik atau tolak menolak antara partikel atau ion yang dapat menimbulkan panas. Panas yang dihasilkan langsung terjadi pada bahan sehingga peningkatan suhu lebih cepat terjadi jika dibanding dengan pemanasan secara konvensional sehingga kerupuk cepat mengalami proses pengembangan saat dipanggang.

Lemak didefinisikan sebagai senyawa organik yang terdapat dalam alam serta tak larut dalam air, tetapi larut dalam pelarut organik non polar seperti suatu hidrokarbon atau dietil eter. Berbagai kelas lipid dihubungkan satu sama lain berdasarkan kemiripan sifat fisisnya tetapi hubungan kimia, fungsional, dan struktur mereka maupun fungsi-fungsi biologis mereka beraneka ragam (Sherman, 1955). Menurut 
Winarno (2004), lemak merupakan zat penting untuk menjaga kesehatan tubuh manusia dan merupakan sumber energi yang lebih efektif dibanding dengan karbohidrat dan protein. Menurut Marsetyo dan Kartasaputra (1990), lemak memiliki fungsi dalam tubuh kita antara lain sebagai penghasil energi, penghemat protein, penghilang panas tubuh, penghasil asam lemak esensial, dan sebagai pelarut vitamin seperti vitamin A,D,E, dan K sehingga dapat dipergunakan oleh tubuh. Kelebihan konsumsi makanan berlemak berdampak tidak baik bagi tubuh. Untuk hasil analisis lemak dapat dilihat pada Tabel 4.

Dari hasil analisis dapat diketahui bahwa semakin tinggi penambahan daging lidah buaya semakin tinggi kandungan lemak pada kerupuk. Hasil analisis kerupuk fortifikasi daging lidah buayabekisar antara 0,25-0,44\%. Menurut Susanti (2007), kenaikan lemak pada kerupuk dipengaruhi oleh kenaikan kadar air pada kerupuk. Pada penelitian ini kadar lemak pada kerupuk dengan penambahan lidah buaya sudah sesuai dengan SNI. Nilai kadar lemak yang rendah pada kerupuk dikarenakan proses pemasakan kerupuk lidah buaya ini tanpa menggunakan minyak melainkan menggunakan microwave.

\subsection{Karbohidrat}

Menurut Winarno (2002), karbohidrat merupakan sumber kalori utama bagi tubuh kita. Karbohidrat juga berperan penting dalam menentukan karakteristik bahan makanan. Dalam penelitian ini analisis karbohidrat dilakukan menggunakan metode by difference yaitu hasil pengurangan dari $100 \%$ dengan kadar air, kadar abu, kadar protein, dan kadar lemak, sehingga kadar karbohidrat dipengaruhi penggurangannya.

Dari Tabel 4. dapat kita ketahui bahwa semakin tinggi konsentrasi penambahan daging lidah buaya, maka semakin kecil kadar karbohidrat pada kerupuk. Terjadinya penurunan karbohidrat dalam kerupuk ini dikarenakan berkurangnya jumlah pati dalam pembuatan kerupuk selain itu faktor lain yang mempengaruhi penurunan kadar karbohidrat yaitu metode analisis yang digunakan. Menurut Jayanti (2009), penurunan karbohidrat ini diduga karena pada analisis ini hanya menggunakan cara perhitungan kasar (proximate analysis). Apabila rata-rata kandungan gizi air, abu, protein, dan lemak meningkat, maka akan mengakibatkan nilai karbohidrat menurun.

\section{Hasil Keseluruhan}

Dari uji masing-masing karakteristik yang meliputi karakteristik sensori, fisik dan kimia yang telah dilakukan dapat direkomendasikan yaitu pada konsentrasi penamahan daging lidah buaya 13,3\%.

\section{KESIMPULAN}

Penambahan daging lidah buaya berpengaruh nyata terhadap karateristik sensori yang meliputi atribut warna, aroma, rasa, tekstur dan keseluruhan. Formulasi kerupuk fortifikasi daging lidah buaya yang paling disukai adalah pada konsentrasi penambahan daging lidah buaya sebesar $13,3 \%$. Penambahan daging lidah buaya berpengaruh nyata terhadap karakteristik fisik yang meliputi daya kembang, tekstur dan higrokopositas serta terhadap karakteristik kimia yang meliputi kadar air, kadar abu, protein total, lemak, dan karbohidrat. Kerupuk fortifikasi daging lidah buaya 13,3\% memiliki karakteristik fisik berupa \% daya kembang sebesar 186,73; higrokopositas sebesar 0,2653 gr dan tekstur sebesar 32,7349 $\mathrm{N}$ serta karakteristik kimia berupa \% kadar air sebesar 3,78\%; kadar abu sebesar 5,75\%; protein total sebesar 3,35\%; lemak 0,29\% dan karbohidrat sebesar $86,82 \%$.

\section{DAFTAR PUSTAKA}

Alinkolis, J. J. 1989. Candy Technology. The AVI Publishing Co. WestportConnecticut

Ariyani, N. 2010.Formulasi Tepung Campuran Siap Pakai Berbahan Dasar Tapioka-Mocaf dengan Penambahan Maltodekstrin Serta Aplikasinya Sebagai Tepung Pelapis Keripik Bayam.Skripsi.Jurusan Pengelolaan Hasil Pertanian. 
Buckle, K.A., R.A. Edwards, G.H. Fleet.,M. Wootton. 1987. Ilmu Pangan. Universitas Indonesia Press, Jakarta.

Buffler, C.R. 1993. Microwave Cooking and Processing. The AVI Publ. Co., New York.

Carrol, L.E. 1989. Hydrocolloid Function to Improve Stability of Microwaveble Field. Baker's Dog 41:52.

Decareau, R.V. 1985. Microwave Energy in Food Processing. Encyclopedia of Food Science. Vol. 3. M.S. Peterson and A. H. Johnson (Ed). The AVI Publishing Company. Inc. Wesport, Connecticut.

DeMan. 1997. Kimia Makanan Edisi Kedua. ITB Bandung. Bandung.

Djumali, Z., I. Nasution, Sailah., M. S. Ma'arif. 1982. Teknologi Kerupuk. Buku Pegangan Petugas Lapang Penyebarluasan Teknologi Sistem Padat Karya.Fatemateta-IPB. Bogor.

Estiasih, T.,Ahmadi, 1998.Teknologi Pengolahan Pangan. Bumi Aksara, Jakarta.

Fumiko, O., K. Yasuko. 2000. A study of kerupuk in Indonesia. Kagoshima Prefectural Jr. College, Natural Science. 47: 17 (Abstr.).

Furnawanthi. 2003.Khasiat dan Manfaat Tanaman Lidah Buaya Si Tanaman Ajaib. Agromedia Pustaka. Jakarta.

Giese, J. 1992. Advances in Microwave Processing. Food Tech. Sep: 118

Goldblith, S.A. 1967. Basic Principle of Microwave and Recent Developments.Advaces Food Res 1:227.

Haryadi. 1990. Pengaruh Kadar Amilosa Beberapa Jenis Pati terhadap Pengembangan Higrokopositas Dan Sifat Inderawi Kerupuk. Lembaga penelitian universitas Gadjah Mada, Yogyakarta.

Hudayan, S.,Siti S.D. 1990. Dasar-Dasar Pengawetan I. Departemen Pendidikan dan Kebudayaan Direktorat Pendidikan Menengah Kejuruan. Jakarta.
Hutchings, J.B. 1999. Food Color and Apperance 2nd. Aspen Publishers, Inc., Gaithersburg, Maryland.

Jatnika. 2009. Meraup Laba Dari Lidah Buaya. Agromedia Pustaka. Jakarta.

Jayanti, A.E. 2009.Pemanfaatan Flavour Kepala Udang Windu (Penaeusmodon) dalam Kerupuk Berkalsium dari Cangkang Rajungan (Portunussp). Program Studi Teknologi Hasil Perikanan Fakultas Perikanan Dan Ilmu Kelautan. Bogor

Kartika, B., Hastuti, P.,Supartono, W. 2002. Pedoman Uji Inderawi Bahan Pangan. Pusat Antar Universitas Pangan dan Gizi UGM.Yogyakarta.

Katz, E., Labuza, T.p. 1981. Effect of water Activity on The Sensori Crispiness and Mechanical Dhefonation of Food Product.J. food Science.Vol 49 (403408).

Koswara, S. 2009. Pengolahan Aneka Kerupuk. Ebookpangan.com.

Kusumaningrum, I. 2009. Analisis Faktor Daya Kembang dan Daya Serap Kerupuk Rumput Laut pada Variasi Proporsi Rumput Laut (Eucheumacottoni).Studi Teknologi Perikanan Jurusan Budidaya Perikaan FPIK Universitas Mulawarman.Samarinda

Lavlinesia.1995. Kajian Beberapa Faktor Pengembangan Volumetrik dan Kerenyahan Kerupuk Ikan.Tesis. Pasca Sarjana, InstitutPertanian Bogor. Bogor.

Legowo, A. M.,Nurwantoro. 2004. DiklatKuliahAnalisisPangan. Program Studi Teknologi Hasil Ternak, Fakultas Peternakan, Universitas Diponegoro.

Martins, S.I., Jongen, W.M.,Boekel, M.A. 2001. A Review of Maillard Reaction in Food and Implication to Kinetic Modelling.Product Design and Quality Managemen Grup, Departmen of Agrotechnology and Food Science, Wageningen University.Netherland. 
Matz,.S.A. 1984. Snack Food Tecnology. The Avi Publishing.Co. Westport Connecticut.

Medikasari. 2000. Bahan Tambahan Makanan :Fungsi dan Penggunaanya Dalam Makanan. Institut Pertanian Bogor.Bogor dalam Surtika Wanti. 2008. Pengaruh Berbagai Jenis Beras Terhadap Aktivitas Antioksidan pada Angkak oleh Monascuspurpureus. Skripsi Jurusan Teknologi Pertanian. FakultasPertanianUniversitasSebelasMar et Surakarta.

Morsy EM. 1991. The Final Technical Report on: Aloe Vera Stabilization and Processing for The Cosmetic, Bevearage and Food Industries ( $\left.5^{\text {rd }} \mathrm{ed}\right)$. United States of America: CITA International.

Muchtadi, T. R.,Sugiyono. 1988. Ilmu Pengetahuan Bahan Pangan. Departemen Pendidikan dan Kebudayaan. Direktorat Jendral Pendidikan Tinggi. Pusat Antar Universitas, Institut Pertanian Bogor. Bogor.

Muliawan, D. 1991. Pengaruh Berbagai Tingkat Kadar Air Terhadap Pengembangan Kerupuk Sagu Goreng. SkripsiJur. TPG, Fak. Tekn.Pertanian, IPB, Bogor. Dalam Jurnal Teknologi dan Industri PanganVol XX No.1 Tahun 2009.

Nurdiani, D. 2012. Minuman Segar dan Menyehatkan dari Lidah Buaya (Aloevera). Universitas Pasundan. Bandung.

Pangkulun, R., A. Budhiarti. 1992. Bawang Putih Dataran Rendah. Penebar Swadaya, Jakarta.

PP Dep Kes RI Nomor 492/Menkes/Per/IV/2010.2010.

Persyaratan Mutu Air Minum. Menteri Kesehatan Republik Indonesia.

Pradipta, I. 2011. Karateristik Fisikokimia dan Sensori Sack Bar dengan Penambahan Salak Pondoh Kering. Skripsi. Fakultas Petranian Universitas Sebelas Maret. Surakarta.
Qinah, E. 2009. Pengaruh Konsetrasi Gula Pasir dan Tepung Ketan tehadap Sifat Kimia, Organoleptik serta Daya Simpan Dodol Ubi Jalar Ungu . Skripsi. Fakultas Kesehatan Masyarakat. Universitas Sumatra Utara. Medan.

Robetson, C.J., 1967. The Practic of Deef Fat Frying. J. Food Tech. 21. (1) : 34-36.

Rockwell, W.C.,E. Lowe, C.C. Huxsol., A.I. Morgan Jr. 1967. Apparatus for Experimental Microwafe Processing. J. Food Tech. vol21 :93-116.

Rosida.2009. Evaluasi Nilai Gizi Pati Resisten Pada Produkdari Empat Jenis Pati. Jurusan Teknologi danI ndustri Pangan, Vol XX No. 1 Th. 2009.UPN Veteran. Jawa Timur. Suarman, W. 1996. Kajian Pembuatan Kerupuk Secara Mekanis. Skripsi. Fakultas Teknologi Pertanian, Institut Pertanian Bogor. Bogor.

Rusmono, M. 1983. Mempelajari Pengaruh Derajat Kehalusan Pulp dan Jumlah Air Pengekstrak Terhadap Mutu Tepung Tapioka. Skripsi. Fakultas Teknologi Pertanian. InstitutPertanian Bogor. Bogor.

Setiawan, H. 1988. Mempelajari Karakteristik Fisiko Kimia Kerupukdari Berbagai Taraf Formulasi Tapioka, Tepung Kentang dan Tepung Jagung. Skripsi. Fakultas Teknologi Pertanian. Institut Pertanian Bogor. Bogor.

Setyowati, A. 2010.Penambaha Natrium Tripolifosfat dan CMC (Carboxxy Methyl Selulose) pada Pembuatan Karak. Jurnal Agri SainsVol (1): 40-49. Program Studi Teknologi Hasil Pertanian, Fakultas Agroindustri, Universitas Mercu Buana. Yogyakarta.

Siswantoro, B. Raharjo, N. Bintoro.,P. Hastuti. 2008. Model Matematik Transfer Panas Pada Penggorengan Menggunakan Pasir. Prosiding Seminar Nasional Teknik Pertanian 2008 Yogyakarta 18-19 November 2008.

SK BPOM RI No.HK. 00.05.5/1639.2003. Pedoman Cara Produksi Pangan yang 
Baik untuk Industri Rumah Tangga.(CPPB-IRT).

Standar Nasional Indonesia. 1999. Kerupuk Udang SNI 01-2713-1999. Badan Standarisasi Nasional Indonesia. Jakarta.

StandarNasional Indonesia. 2000. Garam Beryodium SNI 01-3556-2000. Badan Standarisasi Nasional Indonesia. Jakarta.

Suarman, W. 1996. Kajian Pembuatan dan Kerupuk Secara Mekanis. Skripsi. Fakultas Teknologi Pertanian, InstitutPertanian Bogor. Bogor.

Sugito, J. 1992. Bawang Putih Dataran Rendah. Penebar Swadaya. Jakarta.

Supartono, W. 2000. Pengembangan Produk dan Standarisasi Kualitas Kerupuk Rambak. Seminar Nasional Industri Pangan. Fakultas Teknologi Pertanian. UGM..Yogyakarta.

Susanti, M.R. 2007. Difersifikasi Produk Opakdengan Penambahan Daging Ikan Layur (Trichiuruasp). Skripsi Program Studi Hasil Perikanan, Fakultas Teknologi Industri, Institut Sains danTeknologi AKPRIND.Yogyakarta.

Susanto, T. 1995. Kemungkinan Tulang Ternak Sebagai Bahan Baku Gelatin. Prosiding Seminar Sehari Aspek-aspek Agribisnis Peternakan. Surabaya.

Sya'bani, Arie Ekawati. 1996. Kajian 'Penggorengan' Kerupuk Tapioka Mentah dengan Pemanasan Oven Gelombang Mikro. Skripsi. Fakultas Teknologi Pertanian. Institut Pertanian Bogor. Bogor.
Tahir, S. 1985. Mempelajari Pembuatan dan Karakteristik Kerupukdari Tepung Sagu (Metroxylonsagu R.). SkripsiJurusan Teknologi Pertanian. Fakultas Pertanian. Universitas Hasanudin, Ujung Pandang.

Tofan. 2008. Sifat Fisik dan Organoleptik Kerupuk yang Diberi Penambahan Tepung Daging Sapi Selama Penyimpanan.Skripsi. Program Studi Teknologi Hasil Ternak. Fakultas Perternakan, Institut Pertanian. Bogor

Utami, I. S. 1999. UjiInderawi. THP UGM. Yogyakarta. Hal 87-88.

Wagiyono. 2003. Menguji Kesukaan Secara Organoleptik. Depdiknas.

Winarno, F. G. 1997. Kimia Pangan dan Gizi. Gramedia Pustaka Utama. Jakarta.

Winarno, F. G. 2002. Kimia Pangan dan Gizi. Gramedia Pustaka Utama. Jakarta.

Winarno, F.G. 1992. Kimia Pangandan Gizi.Gramedia Pustaka Utama, Jakarta.

Wiriano, H. 1984. Mekanisme Teknoloi Pembuatan Kerupuk .Balai Pengembangan Makanan Phytokimia. Badan Penelitian dan Pengembangan Industri, Departemen Perindustrian, Jakarta.

Zulfani, R. 1992. Pengaruh Berbagai Tingkat Suhu Penggorengan Terhadap Pola Pengembangan Kerupuk Sagu Goreng. Jurusan Teknologi Pangandan Gizi, Institut Pertanian Bogor. 